\title{
Penggunaan Gambar untuk Mengarang Teks Deskriptif secara Koheren dan Kesatuan
}

\author{
Muchamad Arif \\ Dosen Program Studi PG PAUD \\ Fakultas Keguruan dan Ilmu Pendidikan \\ Universitas Narotama Surabaya \\ muchamad.arif@narotama.ac.id
}

\begin{abstract}
Abstrak: Gambar adalah media pengajaran bahasa yang dapat membuat siswa menyukai untuk menulis. Mereka memiliki ide untuk menulis. Mereka bisa menggambarkan apa yang mereka lihat. Penelitian ini fokus pada koherensi dan kesatuan karangan deskriptif siswa yang ditulis berdasarkan gambar. Ada beberapa cara untuk mengetahui bagaimana koherensi dan bagaimana kesatuan paragraf. Untuk koherensi, ada penggulangan kata benda, penggunaan kata ganti, penggunaan transisi, dan pengaturan kalimat dalam urutan logis. Di sisi lain, untuk kesatuan, penulis hanya membahas satu ide utama. Desain penelitian yang digunakan adalah deskriptif kualitatif. Penelitian ini dilakukan dalam tiga pertemuan. Setiap pertemuan, para siswa mendapat gambar yang berbeda. Selanjutnya, mereka harus menulis dan dikumpulkan di akhir pertemuan. Kemudian, kata-kata, frasa, dan kalimat karangan siswa dianalisis. Selanjutnya, itu dianalisis secara deskriptif. Dari hasil siswa karangan, dapat dilihat bahwa ada perbaikan yang signifikan terhadap kemampuan siswa dalam menulis teks deskriptif. Tampaknya bahwa penggunaan gambar dapat membantu siswa untuk menulis teks deskriptif. Gambar tersebut bisa memberi mereka ilustrasi apa yang akan mereka menulis.
\end{abstract}

Kata kunci: gambar, teks deskriptif, koheren, kesatuan

Abstract: Pictures are language teaching aids that can make students love to write. They have an idea to write. They can describe what they see. This study focuses on the coherence and unity of student descriptive essay written based on the picture. There are several ways to know how coherence and how the unity of a paragraph. For coherence, there are noun repeats, use of pronouns, use of transitions, and setting sentences in a logical order. On the other hand, for unity, the author only discusses one main idea. The research design used is descriptive qualitative. This study was conducted in three meetings. Each meeting, the students get a different picture. Next, they should write and collect at the end of the meeting. Then, the words, phrases, and sentences written by students are analyzed. Furthermore, it was analyzed descriptively. From the results of student essay, it can be seen that there is a significant improvement on the ability of students in writing descriptive text. It seems that the use of images can help students to write descriptive text. The picture can give them an illustration of what they will write.

Keywords: Picture, descriptive text, coherence, unity 


\section{Latar Belakang}

Menulis teks deskriptif bukan pelajaran yang mudah untuk siswa SMP. Bahkan, mereka kadang-kadang merasa bahwa mengarang itu sangat sulit. Mereka tidak tahu apa yang akan mereka tulis. Mereka bingung. Selain itu, mereka berpikir bahwa mereka tidak memiliki bakat dalam menulis. Jarvis (2002) tidak setuju bahwa siswa tidak memiliki bakat dalam menulis. Dia mengatakan bahwa semua siswa mampu menjadi penulis yang sangat baik. Banyak siswa tidak menikmati menulis karena mereka merasa bahwa mereka tidak dapat melakukannya. Ini mungkin membuat mereka minder sehingga mereka tidak memiliki semangat atau tertarik untuk menulis. Ini mempengaruhi karya-karya mereka. Mereka tidak memiliki ide untuk menulis. Mereka bingung. Selain itu, mereka malas untuk menulis.

Kunci belajar menulis adalah merasa percaya diri dalam kemampuan mereka. Mereka akan dapat menulis lebih baik jika mereka merasa nyaman atau yakin dengan kemampuan mereka. Mereka akan memiliki banyak ide untuk ditulis. Ikeguchi (1997) mengatakan 'Masalah yang paling umum yang dihadapi guru dari kelas menulis tidak terletak pada apa yang harus siswa tulis; kesulitan adalah lebih pada bagaimana memotivasi siswa untuk menulis materi yang menarik dan efektif. "Sebenarnya, guru dapat memotivasi dan membuat materi yang menarik dan efektif. Salah satu caranya adalah dengan menggunakan media.

Sadiman (1984: 7) mengatakan bahwa media adalah segala sesuatu yang dapat digunakan untuk menyampaikan pesan dari pengirim ke penerima dalam rangka untuk merangsang pikiran, perasaan, perhatian, dan minat siswa sehingga proses pembelajaran terjadi. Ini memiliki banyak keuntungan. Sadiman (1984: 17-18) mengatakan hal itu dapat membuat materi yang jelas, mengatasi keterbatasan tersebut: ruang, waktu dan ukuran, dan mengaktifkan siswa pasif. Brinton, (2001: 461) menambahkan beberapa keuntungan media. Hal ini dapat memotivasi siswa, memberikan kepadatan informasi dan kekayaan masukan budaya, dan menyediakan kontekstualisasi untuk kegiatan kelas. Salah satu media yang dapat digunakan dalam pengajaran menulis menarik dan efektif adalah gambar. Werff (2003) mengatakan bahwa gambar merupakan sumber yang baik dari bahan untuk berlatih berbicara, mendengarkan, menulis, kosakata dan tata bahasa. Para siswa yang baik di mendapatkan foto-foto orang-orang terkenal, olahraga, dan benda-benda yang mereka sukai.

Berdasarkan uraian di atas, peneliti tertarik tentang penggunaan gambar dalam pengajaran teks deksriptif untuk siswa SMP. Penelitian ini dimaksudkan untuk mengetahui 
bagaimana koherensi dan kesatuan karangan deskriptis siswa SMP. Peneliti memiliki dua rumusan masalah, yakni:

a. Bagaimana koherensi karangan teks deskriptif siswa yang ditulis menggunakan gambar?

b. Bagaimana kesatuan karangan teks deskriptif siswa yang ditulis menggunakan gambar?

\section{Metodologi}

Berdasarkan rumusan masalah di atas, jenis penelitian ini adalah deskriptif kualitatif. Dalam penelitian ini, peneliti melakukan tiga kali observasi dalam kelas bahasa Inggris. Ia mengamati dan melaporkan apa yang terjadi. Di akhir pertemuan, para siswa mengumpulkan karangan mereka. Kemudian, ia meminta guru untuk meminjamkan karangan siswa. Peneliti memfotokopi karangan mereka. Setelah itu, karangan mereka dikembalikan ke guru.

Selanjutnya, peneliti menganalisis karangan siswa berdasarkan rumusan masalah. Peneliti menganalisis hanya pada koherensi dan kesatuan karangan siswa. Kemudian, ia mendeskripsikan koherensi dan kesatuan karangan siswa.

Peneliti melakukan penelitian di SMP Ma'arif XIX Surabaya. Hal ini terletak di Jl. Raya Mastrip no.18 Kemlaten Karang Pilang, Surabaya. Peneliti memilih kelas tujuh SMP dalam melakukan penelitiannya. Ada dua kelas 7 di sekolah tersebut, yakni VII A dan VII B. Peneliti memilih VII B. Ada 27 siswa di kelas; 13 perempuan dan 14 anak laki-laki.

Data penelitian adalah kata-kata, frasa, dan kalimat karangan siswa. Data tersebut digunakan untuk menjawab rumusan masalah pertama dan kedua. Sedangkan, sumber data adalah karangan siswa. Dalam melakukan penelitian, Peneliti mengumpulkan data melalui karangan siswa. Dalam penelitiannya, data dikumpulkan dalam tiga pertemuan. Para siswa diminta untuk menulis teks deskriptif berdasarkan gambar yang guru berikan. Itu diberikan untuk mengetahui kemampuan menulis mereka dengan menerapkan gambar. Selain itu, digunakan untuk mengetahui pemahaman tentang materi terutama koherensi dan kesatuan karangan mereka.

Dalam setiap pertemuan, guru memberi gambaran individu yang berbeda dengan siswa. Penjelasan itu diberikan sebelum mereka mulai menulis dalam rangka untuk membuat 
mereka mengerti tentang materi. Di akhir pertemuan, karangan siswa dikumpulkan. Kemudian, peneliti menganalisisnya untuk mengetahui koherensi dan kesatuannya.

Peneliti menganalisa karangan siswa terutama koherensi dan kesatuan. Kemudian, karangan mereka diberikan tingkat penguasaan untuk mengetahui bagaimana koherensi dan kesatuan. Peneliti membuat kriteria tingkat penguasaan untuk koherensi dan kesatuan seperti di bawah ini.

\section{Koherensi}

\begin{tabular}{|l|l|}
\hline Level & Kriteria \\
\hline Bangat & Semua frase dan kalimat mempunyai urutan yang logis. Semuanya \\
saling mendukung dalam setiap paragraph di karangan tersebut. \\
\hline Bagus & Frase, frase-frase, kalimat atau kalimat-kalimat tidak mempunyai \\
urutan yang logis dalam satu paragraph di karangan tersebut
\end{tabular}

\section{Kesatuan}

\begin{tabular}{|l|l|}
\hline Level & Kriteria \\
\hline Sangat & Setia paragraph mendiskusikan hanya satu ide pokok dalam karangan \\
Bagus & tersebut. \\
\hline
\end{tabular}




\begin{tabular}{|l|l|}
\hline Bagus & $\begin{array}{l}\text { Ada 1 paragraf yang tidak mendiskusikan 1 ide pokok dalam karangan } \\
\text { tersebut. }\end{array}$ \\
\hline Cukup & $\begin{array}{l}\text { Ada dua paragraf atau lebih yang tidak mendiskusikan 1 ide pokok } \\
\text { dalam karangan tersebut. }\end{array}$ \\
\hline Kurang & Tidak ada paragraph yang mendiskusikan 1 ide pokok dalam karangan \\
& tersebut. \\
\hline
\end{tabular}

Setelah karangan siswa diberi tingkat penguasaan, peneliti menjelaskannya secara deskriptif. Dia menjelaskan alasan mengapa karangan punya level yang sangat bagus, bagus, cukup, dan kurang dalam hal koherensi dan kesatuan.

\section{Hasil}

Pertemuan pertama dilaksanakan pada tanggal 29 April 2010. Murid-murid diberikan foto Olga. Mereke mengarang teks deksriptif berdasarkan gambar tersebut. Mereka menghadapi sedikit kesulitan pada saat mengarang deskriptif teks. Hal ini dapat dilihat di tabel di bawah ini.

\begin{tabular}{|l|l|}
\hline Kriteria & Jumlah Siswa \\
\hline Sangat Bagus & 1 \\
\hline Bagus & 23 \\
\hline Cukup & 3 \\
\hline Kurang & 0 \\
\hline
\end{tabular}


Dari tabel di atas, bisa kita lihat bahwa dari 27 siswa, ada 3 siswa mencapai tingkat cukup. Karangan mereka tidak menunjukkan koherensi di beberapa paragraph. Karangan tersebut mempunyai kalimat-kalimat atau frase-frase yang tidak berhubungan dengan kalimat yang lain. Kalimat-kalimat tersebut tidak urut secara logis.

Sementara itu, ada dua puluh tiga siswa bisa mencapai tingkat yang bagus. karangan mereka tidak menunjukkan koherensi dalam satu paragraf. Karanganmereka mempunyai satu kalimat atau frase yang tidak berhubungan dengan kalimat lainnya. Mereka tidak urut secara logis

Kemudian, ada satu siswa bisa mencapai tingkat yang sangat baik. Karangan nya menunjukkan koherensi dalam semua paragraf. Dia mampu menggunakan kata benda berulang, ganti, kata transisi, dan mengatur kalimat secara logis.

Selanjutnya, pertemuan kedua dilakukan pada tanggal 30 April 2010. Para siswa diberi gambar Tukul. Mereka mengarang teks deskriptif berdasarkan gambar. Pada pertemuan kedua, mereka masih menghadapi sedikit kesulitan dalam menyusun teks deskriptif. Hal ini dapat dilihat dari tabel di bawah ini:

\begin{tabular}{|l|l|}
\hline Criteria & Jumlah Siswa \\
\hline Sangat Bagus & 9 \\
\hline Bagus & 17 \\
\hline Cukup & 1 \\
\hline Kurang & 0 \\
\hline
\end{tabular}

Dari tabel di atas, dapat dilihat dari 27 siswa, ada satu siswa mencapai tingkat yang cukup. karangan mereka tidak menunjukkan koherensi dalam beberapa paragraf. Karangan tersebut memiliki beberapa kalimat atau frasa yang tidak berhubungan dengan kalimat lainnya. Mereka tidak urut secara logis. 
Sementara itu, ada tujuh belas siswa bisa mencapai tingkat yang bagus. Karangan mereka tidak menunjukkan koherensi dalam satu paragraf. Karangan mereka tidak menunjukkan koherensi dalam satu paragraf. Karangan tersebut mempunyai satu kalimat atau frase yang tidak berhubungan dengan kalimat lainnya. Mereka tidak urut secara logis.

Kemudian, ada sembilan siswa bisa mencapai tingkat yang sangat bagus. Karangan mereka menunjukkan koherensi dalam semua paragraf. Mereka mampu menggunakan kata benda berulang, ganti, kata transisi, dan mengatur kalimat secara logis.

Selanjutnya, pertemuan ketiga dilakukan pada 3 Mei 2010. Para siswa diberi gambar Pasha. Mereka mengarang teks deskriptif berdasarkan gambar. Dalam pertemuan ketiga, Kebanyakan dari mereka tidak menghadapi kesulitan dalam menyusun teks deskriptif. Hal ini dapat dilihat dari tabel di bawah ini:

\begin{tabular}{|l|l|}
\hline Kriteria & Jumlah Siswa \\
\hline Sangat Bagus & 22 \\
\hline Bagus & 5 \\
\hline Cukup & 0 \\
\hline Kurang & 0 \\
\hline
\end{tabular}

Dari tabel di atas, dapat dilihat dari 27 siswa, ada lima siswa bisa mencapai tingkat yang baagus. karangan mereka tidak menunjukkan koherensi dalam satu paragraf. karangan mereka tidak menunjukkan koherensi dalam satu paragraf. Karangan tersebut mempunyai satu kalimat atau frase yang tidak berhubungan dengan kalimat lainnya. Mereka tidak urut secara logis.

Selanjutnya, ada dua puluh dua siswa bisa mencapai tingkat yang sangat baik. karangan mereka menunjukkan koherensi dalam semua paragaraf. Mereka mampu menggunakan kata benda berulang, ganti, kata transisi, dan mengatur kalimat secara logis. 
Selanjutnya peneliti akan membahas karangan siswa mengenai kesatuan karangan mereka. Untuk pertemuan pertama, kedua, dan ketiga diadakan pada tanggal yang sama karena kegiatan dan karangan yang sama. Peneliti membahasa karangan tersebut berdasarkan koherensi dan kesatuan.

Untuk pertemuan pertama, para siswa diberikan gambar Olga. Mereka mengarang deskriptif teks berdasarkan gambar. Dalam pertemuan pertama, mereka masih mengalami kesulitan dalam mengarang deskriptif teks. Hal ini dapat dilihat dari tabel di bawah ini.

\begin{tabular}{|l|l|}
\hline Kriteria & Jumlah Siswa \\
\hline Sangat Bagus & 1 \\
\hline Bagus & 23 \\
\hline Cukup & 3 \\
\hline Kurang & 0 \\
\hline
\end{tabular}

Dari tabel di atas, dapat dilihat dari 27 siswa bahwa, ada 3 siswa mencapai tingkat cukup. Mereka tidak dapat mengembangkan 1 ide pokok dalam tiap paragraph. Bahkan dalam beberapa paragaraf, mereka mempunyai lebih dari 1 ide pokok dalam satu paragraph.

Sementara itu, ada 23 siswa dapat mencapai tingkat bagus. Mereka tidak bisa mengembangkan 1 ide pokok dalam tiap paragraph. Mereka mempunyai 1 ide pokok dalam 1 paragraf. Kemudian, ada 1 siswa yang dapat mencapat tingkat sangat bagus. Dia dapat mengembangkan 1 ide pokok dalam 1 paragraf. Dia hanya mempunyai 1 ide pokok dalam 1 paragraf. Dia tidak mendiskusikan ide pokok lainnya. 
Pada pertemuan ke dua, para siswa diberikan gambar Tukul. Mereka mengarang teks deskriptif berdasarkan gambar yang diberikan. Pada pertemuan kali ini, mereka masih menghadapi sedikit kesulitan dalam mengarang. Hal ini dapat dilihat pada tabel di bawah ini:

\begin{tabular}{|l|l|}
\hline Kriteria & Jumlah Siswa \\
\hline Sangat Bagus & 10 \\
\hline Bagus & 16 \\
\hline Cukup & 1 \\
\hline Kurang & 0 \\
\hline
\end{tabular}

Dari tabel di atas bisa dilhat dari 27 siswa bahwa ada 1 siswa yang mencapai tingkat cukup. Dia tidak bisa mengembangkan 1 ide pokok dalam tiap paragraph. Bahkan, dalam beberapa paragraph, dia mempunyai lebih dari 1 ide pokok dalam 1 paragraf.

Kemudian, ada 16 siswa yang mencapai tingkat bagus. Mereka tidak dapat mengembangkan 1 ide pokok dalam tiap paragraf. Mereka mempunyai lebih dari 1 ide pokok dalam 1 paragraf. Selanjutnya, ada 10 siswa yang mencapai tingkat sangat bagus. Mereka bisa mengembangkan 1 ide pokok dalam tiap paragraph. Mereka hanya mempunyai 1 ide pokok dalam 1 paragraf. Mereka tidak mendiskusikan ide pokok yang lainnya.

Pada pertemuan ke tiga, para siswa diberikan gambar Pasha. Mereka mengarang teks deskriptif berdasarkan gambar yang diberikam. Pada pertemuan kali ini, Kebanyakan siswa tidak menghadapi kesulitan yang berarti. Hal ini dapat dilihat pada tabel di bawah ini: 


\begin{tabular}{|l|l|}
\hline Kriteria & Jumlah Siswa \\
\hline Sangat Bagus & 22 \\
\hline Bagus & 5 \\
\hline Cukup & 0 \\
\hline Kurang & 0 \\
\hline
\end{tabular}

Dilihat dari tabel di atas, dari 27 siswa terdapat 5 siswa yang mencapai tingkat bagus. Mereka tidak bisa mengembangkan 1 ide pokok dalam tiap paragraph. Mereka mempunyai lebih dari 1 ide pokok dalam 1 paragraf. Kemudian ada 22 siswa yang mencapai tingkat sangat bagus. Mereka bisa mengembangkan 1 ide pokok dalam tiap paragraph. Mereka hanya mempunyai 1 ide pokok dalam 1 paragraf. Mereka tidak mendiskusikan ide pokok yang lainnya.

\section{Kesimpulan}

Setelah melakukan penelitian yang berkaitan dengan penggunaan gambar dalam mengajar menulis teks deskriptif untuk kelas tujuh SMP, tampaknya bahwa gambar adalah bahan yang baik dalam pengajaran menulis. Ini bisa membantu para siswa untuk menulis teks deskriptif. Hal ini juga bisa membuat mereka untuk mengeluarkan ide-ide mereka. Mereka tahu apa yang akan mereka tulis. Hal ini dapat dilihat dari hasil karangan siswa dari pertemuan pertama sampai ketiga. Ini menunjukkan bahwa ada perbaikan yang signifikan pada karangan mereka yang mendapat tingkat yang sangat baik dalam hal koherensi dan kesatuan. Sebagian besar siswa bisa mengekspresikan ide-ide mereka. Mereka memiliki banyak ide untuk menulis. Selain itu, mereka bisa menulis lebih dari tiga paragraf dalam karangan mereka. 


\section{Daftar Pustaka}

Brinton, D. M. 2001.The Use of Media in Language Teaching, in Celce-Murcia (Ed.) Teaching English as a Second or Foreign Language (page 459-488).3rd Ed. Boston: Heinle \& Heinle

Ikeguchi, Dr. Cecilia B.. 1997. Teaching Integrated Writing Skills. The Internet TESL Journal retrieved from http://iteslj.org/Techniques/Ikeguchi-IntegrWrite.html on 21/02/2010 at 03.00 p.m.

Jarvis, Daniel J. 2002. The Process Writing Method. The Internet TESL Journal retrieved from http://iteslj.org/Techniques/Jarvis-Writing.html on http://iteslj.org/Techniques/Massi-WritingTasks.html on 21/02/2010 at 03.00 p.m.

Sadiman, Dr. Arief, M. Se, Drs. R. Rahardjo, Msc., Anung Haryono M.Sc., C. A.S. and Rahardjito.1984. Media Pendidikan. Jakarta: P.T. Raja Grafindo Persada

Werff, Joep van der. 2003. Using Pictures from Magazine. The Internet TESL Journal retrieved from http://iteslj.org/Techniques/Werff-Pictures.html on 21/02/2010 at 03.00 p.m 